\title{
PENINGKATAN HASIL DAN PROSES BELAJAR IPA MATERI SISTEM EKSKRESI MANUSIA MENGGUNAKAN MODEL EKSPLORER ENVIRONMENT DAN EKSPERIMENT LEARNING
}

\author{
BINTI NASHIROTUN \\ Guru IPA Terpadu MTs N 4 Klaten \\ Email : bintinashirotun@gmail.com
}

\begin{abstract}
ABSTRAK
Tujuan penelitian ini adalah untuk mengetahui (1) peningkatan hasil dan proses belajar IPA materi Sistem Ekskresi Manusia dengan Model eksplorer Environment dan eksperiment Learning (E3L). Penelitian dilaksanakan di MTs N 4 Klaten kelas 8E tahun pelajaran 2017/2018 dengan subyek penelitian guru IPA dan siswa kelas 8E yang terdiri dari 17 siswa dan 16 siswi. Jenis penelitian ini adalah penelitian tindakan kelas yang terdiri dari 2 siklus dan masing masing siklus terdiri dari 2 pertemuan, setiap pertemuan mempunyai empat tahap yaitu:(1) tahap perencanaan, (2) tahap pelaksanaan tindakan, (3) tahap pengamatan, dan (4) tahap refleksi. Hasil penelitian dianalisis dengan teknik deskriptif analitik, yaitu dengan menganalisa perubahan hasil belajar dan proses belajar antara keadaan awal dengan siklus 1, menganalisa perubahan siklus 1 dan siklus 2 dan menganalisa perubahan keadaan awal dan siklus 2. Dari hasil penelitian ini dapat diketahui bahwa: Penerapan model eksplorer environment dan eksperiment (E3L) dapat meningkatkan hasil belajar dan proses belajar IPA materi sistem eksresi manusia di kelas 8E MTs N 4 Klaten semester genap tahun pelajaran 2017/2018
\end{abstract}

Kata kunci: Model Eksplorer Environment dan Eksperiment Learning (E3L), hasil belajar, Proses Belajar, Sistem Ekskresi Manusia

\section{PENDAHULUAN}

Berdasar permendiknas Nomor 78 Tahun 2008 tentang Ujian Nasional SMP/MTS Tahun Pelajaran 2017 / 2018 Pasal 6 diketahui bahwa Mata Pelajaran yang diujikan pada UN SMP meliputi: Bahasa Indonesia, Bahasa Inggris, Matematika dan Ilmu Pengetahuan Alam (IPA). Pada Mata Pelajaran IPA khususnya IPA, siswa sering mengalami kesulitan, disebabkan materi yang sangat padat, banyak ditemukan kata kata asing bagi siswa dan gambar - gambar yang rumit. Hal ini Nampak pada hasil belajar mata pelajaran IPA yang belum maksimal, bahkan bisa di bilang rendah. Berdasar análisis hasil ulangan harian siswa kelas 8E MTs N 4 Klaten, ulangan tengah semester maupun ulangan akhir semester gasal tahun 2017, di ketahui bahwa hasil belajar siswa dalam mapel IPA sangat rendah, jauh dari yang di harapkan. Siswa yang mampu mencapai nilai tuntas, di atas KKM (KKM IPA di MTs N4 Klaten 71) kurang dari $20 \%$. 
Hakekatnya nilai rerata tes harian, tes tengah semester dan tes akhir semester mencerminkan hasil belajar dan proses belajar yang meliputi aspek pemahaman dan penerapan konsep serta kinerja ilmiah yang telah dialami siswa selama mengikuti pembelajaran. Jika proses belajar dilaksanakan secara maksimal maka semestinya menghasilkan output berupa nilai hasil belajar yang maksimal. Selain karena kompleksitas materi IPA, rendahnya hasil belajar siswa juga dikarenakan guru kurang menambah kompetensi pedagogiknya, nampak pada proses pembelajaran guru masih mengandalkan cara - cara konvensional dan sering hanya menggunakan model ceramah murni, artinya pembelajaran hanya berpusat pada guru,tanpa di sertai penggunaan model atau penggunaan media pembelajaran yang tepat dengan keadaan siswa . Permasalahan seperti ini juga ditemukan pada proses pembelajaran di MTs 4 Klaten khususnya pada siswa kelas VIII E pada mata pelajaran IPA.

Berdasar temuan beberapa masalah di atas, serta analisis penyebab masalah, di duga ada upaya yang dapat di lakukan untuk meningkatkan hasil belajar IPA ,siswa MTs N 4 Klaten, yaitu dengan menerapkan pembelajaran yang bisa memberi kesempatan kepada siswa untuk melakukan penelaahan, diskusi, pembimbingan langsung oleh guru sampai siswa memiliki kemampuan dalam menyeleseikan soal soal dan kasu - kasus IPA. Berdasar uraian diatas, maka peneliti akan melaksanakan penelitian tindakan kelas ( PTK ) yaitu: Penerapan Model Explorer Environment and Experiment Learning (E3L). Model ini memberi kesempatan pada siswa untuk mampu menelaah soal soal, berdiskusi dan mendapat bimbingan langsung dari guru, sampai siswa mempunyai kemampuan menyeleseikan soal soal IPA (Prasetyo, 2002 ). Sehingga secara langsung bisa meningkatkan Hasil Belajar dan Proses Belajar IPA, Materi Sistem Ekskresi Manusia.

\section{METODE}

Penelitian ini dilakukan di MTs N 4 Klaten Jawa Tengah kelas 8E (17 siswa, 16 siswi), di laksanakan pada bulan Februari sampai dengan Mei 2018. Data dikumpulkan menggunakan teknis tes dan nontes. Data yang terkumpul berupa hasil belajar siswa dan hasil pengamatan, dan hasil laporan praktikum. Analisis data menggunakan teknik deskriptif analitis yaitu dengan menganalisa hasil belajar dan aktivitas siswa pada keadaan awal dengan hasil belajar dan aktivitas siswa pada siklus 1 dan 2. Indikator keberhasilan tindakan ini adalah jika siswa mampu memperoleh nilai minimal 70 dan terjadi peningkatan hasil belajar dan kualitas laporan praktikum siswa pada keadaan awal, siklus 1 dan siklus 2 . 


\section{HASIL DAN PEMBAHASAN}

\section{a. Deskripsi Keadaan Awal}

Tabel 1. Deskripsi Hasil Belajar Keadaan Awal

\begin{tabular}{|l|l|l|}
\hline No. & \multicolumn{1}{|c|}{ Uraian } & Nilai \\
\hline 1. & Nilai terendah & 3,00 \\
\hline 2. & Nilai tertinggi & 7,70 \\
\hline 3. & Nilai tuntas & 4,18 \\
& & $18,2 \%$ \\
\hline
\end{tabular}

Tabel 2 : Ketuntasan Hasil Belajar pada Keadaan Awal

\begin{tabular}{|c|l|c|c|}
\hline No. & \multicolumn{1}{|c|}{ Nilai } & Jumlah Siswa & Persentase \\
\hline 1. & Tuntas $>/=70$ & 6 & 18,2 \\
\hline 2. & Belum Tuntas $<70$ & 27 & 81,8 \\
\hline & Jumlah & 33 & 100 \\
\hline
\end{tabular}

Data hasil belajar dalam kedua tabel di atas di jadikan acuan dalam membuat perencanaan tindakan pada siklus 1

\section{b. Deskripsi Keadaan Siklus 1}

Pengamatan perubahan hasil belajar keadaan awal ke siklus I disajikan dalam tabel 3 dan 4

Tabel 3 : Perubahan Hasil Belajar Dari Keadaan Awal ke Siklus 1

\begin{tabular}{|l|c|c|}
\hline Hasil Belajar & \multirow{2}{*}{$\begin{array}{c}\text { Keadaan } \\
\text { Awal }\end{array}$} & Siklus \\
\cline { 3 - 3 } & $18,2 \%$ & $54 \%$ \\
\hline Tuntas & $81,8 \%$ & $46 \%$ \\
\hline
\end{tabular}


Tabel 4 : Kesan Siswa Setelah Pembelajaran Siklus 1

\begin{tabular}{|l|l|c|c|}
\hline \multirow{2}{*}{ No } & \multirow{2}{*}{ Kesan Siswa } & \multicolumn{2}{|c|}{ Siklus 1 } \\
\cline { 3 - 4 } & & Prosentase & Jumlah \\
\hline 1 & Sangat senang & $76 \%$ & 25 siswa \\
\hline 2 & Termotivasi & $70 \%$ & 23 siswa \\
\hline 3 & Tambah wawasan & $76 \%$ & 25 siswa \\
\hline 4 & Penasaran & $67 \%$ & 22 siswa \\
\hline 5 & Lebih bersemangat & $82 \%$ & 27 siswa \\
\hline
\end{tabular}

\section{c. Deskripsi Keadaan Siklus 2}

Pengamatan perubahan hasil belajar keadaan awal ke siklus 1 dan ke siklus 2 di sajikan pada tabel 5 dan tabel 6.

Tabel 5 : Hasil Belajar Siswa keadaan Awal, Siklus 1 dan Siklus 2

\begin{tabular}{|l|c|c|c|}
\hline \multirow{2}{*}{ Hasil Belajar } & Keadaan & \multicolumn{2}{c|}{ Siklus } \\
\cline { 3 - 4 } & Awal & 1 & 2 \\
\hline Tuntas & $18,2 \%$ & $54 \%$ & $88 \%$ \\
\hline Belum tuntas & $81,8 \%$ & $46 \%$ & $12 \%$ \\
\hline
\end{tabular}

Tabel 6 : Kesan Siswa Setelah Pembelajaran Siklus 1 Dan Siklus 2

\begin{tabular}{|l|l|c|c|}
\hline \multirow{2}{*}{ No } & \multicolumn{1}{|c|}{ Kesan Siswa } & \multicolumn{2}{|c|}{ Siklus ke } \\
\cline { 3 - 4 } & & 1 & 2 \\
\hline 1 & Sangat senang & $76 \%$ & $88 \%$ \\
\hline 2 & Termotivasi & $70 \%$ & $85 \%$ \\
\hline 3 & Tambah wawasan & $76 \%$ & $79 \%$ \\
\hline 4 & Penasaran & $67 \%$ & $79 \%$ \\
\hline 5 & Lebih bersemangat & $82 \%$ & $97 \%$ \\
\hline
\end{tabular}

Sistem Ekskresi manusia merupakan salah satu materi IPA yang pembelajaranya akan lebih efektif jika disertai praktikum. Akan tetapi karena keterbatasan sarana dan prasarana yang ada di MTs $\mathrm{N} 4$ Klaten (belum memiliki laboratorium IPA), maka pembelajaran materi ini hanya dengan menerapkan metode ceramah, untuk membuktikan zat-zat yang di keluarkan oleh organ ekskresi , guru hanya bercerita tentang proses praktikum, kemudian siswa hanya mencatat. Pembelajaran dengan ceramah , aktivitas di kelas hanya berpusat pada guru, siswa cenderung pasif. Keadaan tersebut akan membuat suasana belajar kurang menyenangkan , kurang menarik sehingga siswa akan mudah bosan , karena aktivitas siswa hanya mendengar dan mencatat, menghafal. Hal ini berefek rendahnya daya tangkap dan daya ingat siswa, tentang materi yang diterima, tentunya akan menyebabkan rendahnya hasil belajar siswa. Penerapan model E3L (Eksplorer 
Environment and Eksperiment), diduga dapat mengatasi kekurangan-kekurangan yang ada pada metode ceramah. Model E3L ini siswa diberi kesempatan untuk melakukan praktikum di kelas, dengan peralatan sederhana yang bisa di dapat di lingkungan sekitar. Dengan model pembelajaran ini, siswa dapat memperoleh pengalaman langsung, melihat dan membuktikan adanya zat-zat sisa metabolisme yang sudah tidak di butuhkan oleh tubuh , kemudian di keluarkan /di ekskresikan melalui organ ekskresi. Model pembelajaran E3L memberi kesempatan pada siswa untuk lebih aktif berdiskusi dengan guru atau dengan sesama siswa, dalam menelaah soal-soal atau kasus yang di hadapi siswa. Pengalaman langsung yang dijalani siswa ini , akan meningkatkan pemahaman dan daya ingatnya tentang materi yang dipelajari. Hal ini akan berakibat langsung pada peningkatan hasil belajar siswa, karena siswa lebih terampil memahami dan menyeleseikan soal-soal yang kontekstual tentang zat-zat yang di ekskresikan organ ekskresi dan mampu lebih memahami tentang gangguan -gangguan pada organ ekskresi. Hasil penelitian menunjukkan peningkatan hasil belajar yang signifikan dan meninggalkan kesan-kesan yang menyenangkan dalam diri siswa. Model in bisa di katakan unggul, karena pelaksanaanya bisa dilaksanakan di kelas , dengan peralatan sederhana, sehingga model ini penggunaanya layak untuk di kembangkan, dalam materi-materi yang lainya, atau dalam mapel lainya.

\section{KESIMPULAN DAN SARAN}

Hasil Penelitian dengan judul peningkatan hasil dan proses belajar IPA materi sistem ekskresimanusia menggunakan model E3L, memperoleh kesimpulan sebagai berikut :

a. Proses pembelajaran dengan menggunakan model E3L adalah sebagai berikut: Tahap 1: Motivasi, Tahap 2: Eksplorer Environment, Tahap 3: Eksperimen, Tahap 4: Evaluasi.

b. Dengan menggunakan model E3L, hasil belajar siswa Kelas 8E MTs N 4 Klaten semester Genap tahun 2018 mapel IPA mengalami peningkatan keadaan awal, siklus 1 dan siklus 2. Peningkatan tersebut adalah sebagai berikut: Pada keadaan awal siswa yang belum tuntas ada 27 siswa yang tuntas 6 siswa. Pada siklus 1, siswa yang belum tuntas turun menjadi 15 , siswa yang tuntas naik menjadi 18 . Pada siklus 2 , siswa yang belum tuntas berkurang lagi, tinggal 4 siswa, siswa yang tuntas naik menjadi 29.

c. Kesan siswa selama mengikuti proses pembelajaran dari siklus 1 dan 2 positif, yakni sebagai berikut: (a) siswa yang merasa sangat senang pada siklus 1 ada 25 dan siklus 2 ada 29, (b) siswa yang termotivasi pada siklus 1 ada 23 dan siklus II ada 26, (c) siswa yang merasa ada tambahan wawasan pada siklus 1 ada 25 dan siklus II ada 26, (d) siswa yang merasa penasaran pada siklus ada 22 dan siklus 2 ada 26, (e) siswa yang merasa lebih bersemangat pada siklus 1 ada 26 dan siklus 2 ada 32 siswa.

d. Hasil tindakan dalam PTK ini dapat di terima secara teori sehingga layak untuk di kembangkan penggunaanya. 


\section{DAFTAR PUSTAKA}

Arikunto, S, Suhardjono, dan Supardi. 2006. Penelitian Tindakan Kelas. Jakarta: Bumi Aksara.

Hamalik, O. 2004. Proses Belajar Mengajar. Jakarta: Bumi Aksara.

Legowo, T.2007. Upaya Peningkatan Hasil Pembelajaran melalui "Environment Based Learning". Kabupaten Semarang:PTK.

Purnomo, B. 2007. Aktualisasi Pembelajaran Teks Narrative dengan Menggunakan Multimedia melalui Model Bangmogi. Kebumen:PTK..

Rudi Susilana, M.Si dan Cepi Riyana, M.Pd. 2007. Media Pembelajaran, Hakikat, Pengembangan, Pemanfaatan, dan Penilaian, Seri Pembelajaran Efektif. Jakarta : Raja Grafindo Persada.

Sanjaya, Wina (2008). Strategi Pembelajaran Berorientasi Standar Proses Pendidikan. Jakarta:Kencana, Prenada Media Group.

Slameto, 1988. Belajar dan Faktor-faktor yang Mempengaruhinya. Jakarta: Bina Aksara.

Supardi dan Suharjono (2011).Strategi Menyusun Penelitian Tindakan Kelas Berdasarkan Permenpan dan Reformasi Birokrasi No. 16 Tahun 2009. Yogyakarta: Andi Ofset.

Suprijono, Agus (2011), Cooperative Learning; Teori dan Aplikasi Paikem, Yogyakarta: Pustaka Pelajar

Tilaar, H.A.R. 2002. Perubahan Sosial dan Pendidikan: Pengantar Pedagogik Transformatif untuk Indonesia. Jakarta: Grasindo.

Wina Sanjaya, DR., M.Pd., 2008. Perencanaan dan Desain Sistem Pembelajaran. Jakarta. Kencana Prenada Media Group.

Wiriaatmadja,R. 2005. Model Penelitian Tindakan Kelas. Bandung. PT Remaja Rosdakarya.

Yusetyowati, (2011), Penggunaan Drama Dalam Pengajaran Bahasa Inggris, http://isjd.pdii.lip.go.id/admin/jurnal/438550553.pdf/16-02-2018.8.00 